\title{
Market Condition and Flight to Quality: On Perspective of Social Responsibility Performance "Class Insurance” Effect
}

\author{
Yuting Chen \\ School of Management, Jinan University, Guangzhou, China \\ Email: 13535057057@163.com
}

How to cite this paper: Chen, Y. T. (2020). Market Condition and Flight to Quality: On Perspective of Social Responsibility Performance "Class Insurance" Effect. Modern Economy, 11, 750-762.

https://doi.org/10.4236/me.2020.113055

Received: February 17, 2020

Accepted: March 27, 2020

Published: March 30, 2020

Copyright $\odot 2020$ by author(s) and Scientific Research Publishing Inc. This work is licensed under the Creative Commons Attribution International License (CC BY 4.0).

http://creativecommons.org/licenses/by/4.0/

\begin{abstract}
When the market environment is not good and the uncertainty increases, the fund has flight to quality behavior. The reputation capital formed by enterprises' active social responsibility has the function of "Class Insurance", which can prevent a sharp decline in stock prices and market value losses when negative events occur; then, will the fund manager turn the fund portfolio to the society when the market environment is not good? Using the open-end fund samples from 2010 to 2017, this paper empirically tests the relationship among corporate social responsibility, market environment and flight to quality. The results show that when the market condition is not good, the fund has a higher demand for hedging, and it tends to shift its investment portfolio to more stocks with high corporate social responsibility performance that can meet its hedging demand and have "like insurance" effects; The study also found that the fund's safe investment transfer behavior had a positive impact on fund performance and fund return volatility.
\end{abstract}

\section{Keywords}

Market Condition, Flight to Quality, Social Responsibility Performance,

"Class Insurance" Effect

\section{Introduction}

In mid-September 2017, Shanghai Jiaotong University Shanghai Advanced Institute of Finance, Xingquan Fund, and Delin News Agency jointly sponsored the "China Decade of Socially Responsible Investment". At the summit, Xingquan Fund and SynTaoRonglv jointly released the "China Responsible Investment Decade Report", which showed "As of the end of August, the number of respon- 
sible investment-related funds in the Chinese fund market has reached 62, and the net asset value scale has exceeded 50 billion yuan, $74.9 \%$ of the public investors pay attention to and understand responsible investment and green finance, but $80 \%$ of investors still have concerns or prejudice about reducing social responsibility investment. "Most of these concerns and prejudices stem from the fact that no consensus has been reached on the "corporate social responsibility-financial performance" relationship from academia or practice. It is precisely because of the above-mentioned dilemma that academia has conducted research on the Social Responsibility Performance "Class Insurance" Effect. Godfrey (2005) firstly stated that when a company encounters a negative event, corporate social responsibility can form a "reputation capital", and the company's early social responsibility behavior will effectively protect the reputation of the enterprise reduces the losses suffered by the enterprise and slows down the loss of shareholder wealth. The emergence of such research also provides investors with a new opportunity for socially responsible investment.

As the main force of socially responsible investment, will funds focus on the concept of socially responsible investment when making portfolio decisions? In portfolio allocation, will then focus not only on corporate financial performance, but also on corporate social responsibility performance? Domestic scholars have not been unanimously recognized in this regard. The reason is: Compared with western institutional investors, Chinese fund managers have stronger information advantages and more significant short-term profit-seeking, which makes them over-emphasis on short-term benefits and neglect of corporate social responsibility performance (Sun et al., 2018).

However, since 2014, the Chinese A-share market has experienced ups and downs. The "swell" of the stock price, especially the risk of a stock price crash caused by the "slump", which may cause huge losses to investors "wealth, shake investors" confidence on the capital market and may lead to the healthy development of the real economy. In the presence of uncertainties in the financial market, rational investors will buy defensive investment products, transfer to relatively safe investment projects, and conduct safe investment transfers to achieve the goal of avoiding losses as much as possible ( $\mathrm{Ng}, 2011)$. Then, as a professional institutional investor, will the fund invest more in stocks with higher corporate social responsibility that can meet its risk aversion needs under the conditions of poor market environment and high uncertainty? Will this flight to quality behavior based on the corporate social responsibility performance "Class Insurance" effect bring better performance to the fund?

Therefore, from the perspective of social responsibility performance "Class Insurance" effect, this paper explores whether the fund will invest more in stocks with good social performance in order to avoid risks when the market environment is not good, so as to make safe investment transfers. This paper finds that during the bear market period, the fund's willingness to hedge risks increased, and there has flight to quality behavior. When making investment decisions, it tended to invest more in high-performance corporate social responsibility per- 
formance stocks with "class insurance" effects to meet its risk aversion Insurance demand. At the same time, the study also found that the fund's use of corporate social responsibility for safe investment transfer can bring higher performance and better performance stability when the market environment is not good.

\section{Literature Review and Hypothesis Development}

\subsection{Literature Review}

\subsubsection{Corporate Social Responsibility “Class Insurance” Effect}

Earlier studies on the economic consequences of corporate social responsibility mainly focused on the relationship between corporate social responsibility performance and their economic performance. However, (Margolis \& Walsh, 2013) pointed out that corporate social performance measures are too broad and comprehensive, and the relationship between social responsibility and economic performance is disturbed by many other variables, so there are no consistent conclusions can be drawn. Many scholars believe that social responsibility has positive impacts on corporate financial performance (Zhang et al., 2013) and has positive market responses. Other studies suggest that corporate social responsibility is negatively related to financial performance (Giuli \& Kostovetsky, 2014) and has negative market responses (Becchetti et al., 2012).

In recent years, scholars have begun to explore the impact of social responsibility from the perspective of detailed corporate financial and operating performance, and have launched studies on the effects of corporate social responsibility "Class Insurance" Effect. Godfrey (2005) has made significant contributions in the field of corporate social responsibility reputation insurance effects, has clarified firstly the mechanism of corporate social responsibility reputation insurance effects. Corporate social responsibility performance can be used as a risk management tool to avoid or reduce market value loss when negative events occur (Godfrey, 2005; Shiu \& Yang, 2015). Lins et al. (2017) show that companies with higher levels of social responsibility have more social capital, lower stock prices and higher stock returns during the financial crisis. Using event research methods, it is found that after a company has a negative legitimacy event; positive social responsibility performance can increase the company's cumulative excess income, reduce the value loss, and strengthen the ability of businesses to recover from crisis (Godfrey et al., 2009).

At the same time, many domestic scholars have launched academic research on the reputation insurance effect of corporate social responsibility. Fu and $\mathrm{Ge}$ (2017) found that when companies face litigation risks, donations can alleviate the undesired economic consequences. Song et al. (2017) show that corporate social responsibility information disclosure mainly reduces the risk of stock price crash through the effect of reputation insurance. For companies with a more proactive social responsibility strategy, their "class insurance" effect is more obvious (Chen, 2014). Corporate social responsibility is significantly positively correlated with the cumulative abnormal return rate, the reason is that the company's per- 
formance of social responsibility has a "class insurance" effect, which can effectively mitigate the impact of strong environmental regulations.

\subsubsection{Corporate Social Responsibility Performance and Investor Behavior}

Regarding the impact of corporate social responsibility on institutional investors' stock preferences, there are two hypotheses: the short-sighted investor hypothesis and the super-investor hypothesis. The super-investor hypothesis believes that social responsibility is a prerequisite for institutional investors to make investment decisions, because choosing companies with good social responsibility can reduce the potential risks of investment decisions. Mao et al. (2012) established a linear model to analyze the relationship between China's 6 types of institutional investors' shareholding preferences and corporate social responsibility, and the results showed that fund shareholding preferences and social responsibility performance were significantly positively correlated. Jiang \& Xu (2012) used the event research method to find that investors believed that those with low corporate social responsibility scores would be dishonest and would not choose the company for investment.

The short-sighted investor hypothesis believes that institutional investors do not pay enough attention to corporate social responsibility due to internal and external pressures, which is more short-sighted than individual investors. Internal pressure means that if institutional investors consider social responsibility too much when making investment decisions, they will reduce the choice of investment options, which will reduce the diversity of investments and increase investment risks in the short term. External pressure is concerned that social responsibility is not good for short-term performance assessment, and most of the concern is social investment. Wang took China's listed companies as the research object, and also got the same conclusion, i.e., the social performance of the company is subordinate to the economic performance. Li \& Lu (2015) found that corporate environmental performance has a positive impact on the institutional investor's shareholding ratio, and the impact of environmental performance is only reflected in the shareholding of long-term institutional investors, excluding the shareholding of short-term institutional investors.

\subsubsection{Market Condition and Fund Investment Behavior}

When discussing fund managers' investment behavior and investment decisions, different market conditions need to be considered (Brown et al., 1996). Kao et al. (1998) studied the timing of fund selection in different market states; Capocci et al. (2005) explored the performance and sustainability of hedge funds in different market states. Research on fund risk-adjusted behavior in the context of tournaments (Brown et al., 1996; Kempf et al., 2009), fund investment style drift, and performance (Ainsworth et al., 2008), which all take into account market conditions. In addition, under different market conditions, China's investor behavior has shown significant differences. Xiao (2013) believes that under different stock market cycles, there is a significant asymmetry in the choice of fund 
investors. During the bull market, the fund was keen on improving performance, and during the bear market, the fund's motivation to improve performance declined. Xiao (2016) found that the expected risk adjustment of the winners and losers varies according to the performance of the stock market. Its ranking-risk adjustment sensitivity is significantly positively correlated with the market strength.

Due to the significant differences in fund investment behavior under different market conditions, in recent years, many scholars have begun to focus on whether investors will make safe investment transfers when market volatility is large and uncertainty is large and whether the investors would become more cautious when choosing and deploying, from high-risk high-yield investments to value-type, high-quality, and low-risk investments. Ng (2011) shows that in a period of increasing political uncertainty leading to large market fluctuations, investor demand for lower earnings quality stocks will decline because of the greater uncertainty and adverse selection of these stocks. Jiang et al. (2017) used 2006-2015 open-end fund heavy storage holding data to test whether the fund's investment behavior in the bull and bear market is consistent with value investment. Research shows that funds follow value investment in bear markets; while in bull markets, value investments are ignored due to the selective expression of information advantages of funds in different market conditions.

\subsection{Hypothesis Development}

Existing studies have shown that under different market conditions, there are significant differences in the investment behavior of fund managers. Funds are abundant in the bull market. Fund managers are greatly affected by performance rankings, pay more attention to the improvement of short-term performance, attract more capital flows, and reward incentives dominate (Xiao, 2013). The positive selection of stocks through social responsibility adds constraints to the selection of portfolio ranges (Wright \& Hiller, 1995); Industries such as alcohol and tobacco with high returns and high risks are excluded from the portfolio selection range during negative selection process, which affects fund performance and reduces the return on investment (Capelle-Blancard \& Monjon, 2012). Therefore, during the period of market upswing, fund managers may ignore corporate social responsibility investment due to the pursuit of short-term interests. However, during the bear market, market capital was not sufficient, the motivation of fund managers to obtain more capital flows to improve performance declined, and the risk of termination and the redemption of investors due to poor performance were more affected. The investment behavior of fund managers Tends to be conservative and conservative (Xiao, 2016). At this time, the fund's willingness to hedge risks is stronger, so that safe investment transfers are made, and the investment is shifted to defensive assets such as value (Jiang et al., 2017), high liquidity and low volatility (Vayanos, 2004). When the market condition is not good, the moral reputation capital formed by companies that can not only positively affect the behavior of investment stakeholders, but also reduce the overall 
business risk of the company and enhance its ability to resist risks; the more important is that it can reduce the adverse effects caused by negative events and effectively avoid the potential impact of risk crises on stock prices and market value losses (Godfrey, 2005). Based on the above analysis, this paper believes that when the market condition is not good, fund managers' investment behavior will be more cautious and conservative, and their risk-averse will be stronger, so that they will shift portfolio assets to a corporate society that can meet their hedging needs and has a strong ability to withstand risks. Invest in companies with higher accountability. Therefore, this paper proposes Hypothesis:

During the bear market, the fund will shift its portfolio assets to more stocks with higher corporate social responsibility performance.

\section{Research Design and Samples}

\subsection{Data Sources}

This paper selects the stock funds and mixed partial stock funds in China's open-end funds from 2010 to 2017 as sample objects, which can reflect the ability of fund managers to actively manage and invest in stock selection. The reason for the lack of the last two years is that corporate social responsibility data is disclosed by year, and it's too expensive to obtain the latest year's social responsibility data when writing this article. So the time series selected in this article is from 2010 to 2017. this time series is missing the data of the last two years Sample fund holding code, the number of shares, stock market value, as well as fund size, fund turnover rate and other fund-level data from the Guotai An database; stock-level data such as daily standard deviation, book value ratio, asset return, the system risk $\beta$ value and the factors in the three-factor and four-factor models come from Ruisi database; the corporate social responsibility rating data comes from Runling Global (RKS) database.

\subsection{Variable Definitions}

\subsubsection{Market Segmentation}

This paper refers to the division method of Cai and Liu (2012), and uses the return rate of the mid-year market index of the A-share market to describe the current market state. The reason why the mid-year market index returns are used to determine the market status of the year is because the fund manager attaches great importance to the performance level of the fund in the first half of the year and will decide what investment strategy to adopt in the second half of the year based on the performance level of the first half of the year (Brown et al., 1996; Xiao, 2016). Table 1 lists the Shanghai A-share index from 2010 to 2017, including not only the index return in the first half of the year but also the index return for the entire year.

\subsubsection{Flight to Quality (FTQ)}

The calculation of FTQ is based on the method of Chen et al. (2016), including the following steps. First, the corporate social responsibility performance of each 
Table 1. SSE A-share index and index earnings.

\begin{tabular}{ccccccc}
\hline Annual & $\begin{array}{c}\text { Year-To-Date } \\
\text { Index }\end{array}$ & $\begin{array}{c}\text { Mid-Year } \\
\text { Index }\end{array}$ & $\begin{array}{c}\text { Year-End } \\
\text { Index }\end{array}$ & $\begin{array}{c}\text { First Half Index } \\
\text { Earnings }\end{array}$ & $\begin{array}{c}\text { Second Half Index } \\
\text { Earnings }\end{array}$ & $\begin{array}{c}\text { Market } \\
\text { Status }\end{array}$ \\
\hline 2010 & 3402.31 & 2514.16 & 2940.24 & -0.261 & -0.1358 & Bear \\
2011 & 2987.03 & 2893.53 & 2304.12 & -0.0313 & -0.2286 & Bear \\
2012 & 2272.67 & 2330.5 & 2376.04 & 0.0254 & 0.0455 & Bull \\
2013 & 2384.19 & 2071.26 & 2214.49 & -0.1313 & -0.0712 & Bear \\
2014 & 2207.56 & 2144.75 & 3389.4 & -0.0285 & 0.5354 & Bear \\
2015 & 3511.05 & 4479.9 & 3704.3 & 0.2759 & 0.055 & Bull \\
2016 & 3701.58 & 3068.46 & 3242.99 & -0.0007 & -0.0104 & Bear \\
2017 & 3251.35 & 3327.14 & 3450.98 & 0.0014 & 0.0033 & Bull \\
\hline
\end{tabular}

year is sorted in ascending order, and the cutoff points are divided by $30 \%, 40 \%$, and 30\%. The division method is similar to Hirshleifer et al. (2012). Second, according to the shareholding of the fund, all the shares held by the fund are assigned to different corporate social responsibility rating groups (r), for each fund, calculate the high, medium and low three corporate social responsibility performance groups included in the combination weighting of the shares $W_{r, t}=\sum_{i=r}^{n} W_{i, t}$, and a stock weight is the market value of a stock held as a proportion of the total market value of all stocks held by the Fund. Finally, the FTQ is calculated, and the combined weight of the high social responsibility performance group is subtracted from the combined weight of the low social responsibility group. The higher the FTQ value, the more likely the fund's portfolio is to hold high-performance stocks, the greater the degree of safe investment transfer.

\subsubsection{Control Variables}

The control variable definitions are shown in Table 2.

\subsection{Research Design}

This paper refers to Chen et al. (2016), and establishes a model (1) to test hypothesis to determine whether the fund manager will invest in stocks with higher corporate social responsibility performance when the market condition is not good.

$$
\begin{aligned}
\text { FTQ }= & \beta_{0}+\beta_{1} \text { condition }+\beta_{2} \text { LnTNA }+\beta_{3} \text { Turnover }+\beta_{4} \text { Fund_VOL } \\
& +\beta_{5} \text { Fund_BM }+\beta_{6} \text { Fund_VOA }+\beta_{7} \text { Difbeta }+\beta_{8} \text { Difsize } \\
& +\beta_{9} \text { Difturnover }+\beta_{10} \text { Difbm }+\varepsilon_{i}
\end{aligned}
$$

\subsection{Descriptive Statistics}

Descriptive statistics of the variables are shown in Table 3. In the descriptive statistics, the mean value of FTQ is 0.0187 , which indicates that the fund's investment in stocks with high corporate social responsibility has a weight of $1.8 \%$ more than that in investments with low corporate social responsibility. 
Table 2. Control variable definitions.

\begin{tabular}{|c|c|}
\hline Control Variable & Definitions \\
\hline LnTNA & Taking a natural equivalent of the fund's net assets at the end of the period \\
\hline Turnover & $\begin{array}{l}\text { The ratio of the fund's stock trading volume in year } t \text { (the average cost of buying } \\
\text { stocks and the income of selling stocks) to the average amount of net assets at the } \\
\text { beginning and end of the period }\end{array}$ \\
\hline Fund_VOL & $\begin{array}{l}\text { The weighted average of the standard deviation of daily returns on the stocks held } \\
\text { by the fund }\end{array}$ \\
\hline Fund_BM & $\begin{array}{l}\text { The weighted average of the book-to-market ratio of the stocks held by the fund } \\
\text { gets the book-to-market ratio at the fund level }\end{array}$ \\
\hline Fund_ROA & $\begin{array}{l}\text { The weighted average of the return on assets of the stocks held by the fund repre- } \\
\text { sents the company performance at the fund level }\end{array}$ \\
\hline Difbeta & $\begin{array}{l}\text { First, all the stocks held by the fund in each year are sorted according to the } \beta \\
\text { value of the stock CAPM and divided into three groups: low, medium, and high; } \\
\text { then the weights of the stocks held by fund i belong to the low, medium, and high } \\
\text { groups. Finally, subtract the weight of the group with the high } \beta \text { value from the } \\
\text { weight of the group with the low } \beta \text { value }\end{array}$ \\
\hline Difsize & $\begin{array}{l}\text { First, all the stocks held by the fund in each year are sorted according to the } \\
\text { market value of the stock and divided into three groups: low, medium, and high; } \\
\text { then the weights of the shares held by fund i belong to the low, medium, and high } \\
\text { groups; Finally, subtract the weight of the group with the low stock market value } \\
\text { from the weight of the group with the high stock market value }\end{array}$ \\
\hline Difturnover & $\begin{array}{l}\text { First, all the stocks held by the fund in each year are sorted according to the stock } \\
\text { turnover rate and divided into three groups: low, medium, and high; then the } \\
\text { stocks held by fund } i \text { belong to the low, medium, and high weights; Finally, } \\
\text { subtract the weight of the group with the low turnover rate from the weight of the } \\
\text { group with the high turnover rate }\end{array}$ \\
\hline Difbm & $\begin{array}{l}\text { First, all the stocks held by the fund in each year are sorted according to the book } \\
\text { value ratio of the stock, divided into three groups of low, medium and high; then } \\
\text { the weight of the shares held by fund } i \text { belong to the low, medium and high } \\
\text { groups; Finally, subtracting the lower book value from the weight of the group } \\
\text { with the higher book value than the group weight means the weight }\end{array}$ \\
\hline
\end{tabular}

Table 3. Descriptive statistics.

\begin{tabular}{cccccc}
\hline Variables & Number of Samples & Mean & Standard Deviation & Min & Maximum \\
\hline FTQ & 2740 & 0.0187 & 0.0724 & -0.2743 & 0.3604 \\
Condition & 2740 & 0.5558 & 0.497 & 0 & 1 \\
LnTNA & 2740 & 20.7563 & 1.4714 & 16.2117 & 23.9896 \\
Turnover & 2740 & 3.2387 & 2.9907 & 0.0728 & 31.2548 \\
Fund_VOL & 2740 & 0.0235 & 0.0082 & 0.0007 & 0.0557 \\
Fund_BM & 2740 & 0.4012 & 0.1322 & 0.0077 & 0.8477 \\
Fund_ROA & 2740 & 0.06 & 0.0237 & -0.0088 & 0.168 \\
Difbeta & 2740 & -0.0075 & 0.2233 & -0.8591 & 0.7632 \\
Difsize & 2740 & 0.2201 & 0.2869 & -0.9352 & 0.8862 \\
Difturnover & 2740 & -0.0661 & 0.2465 & -0.8215 & 0.9081 \\
Difbm & 2740 & 0.0066 & 0.3064 & -0.8858 & 0.9163 \\
\hline
\end{tabular}




\section{Hypothesis Testing}

\subsection{Regression Analysis}

Table 4 shows the test results of hypothesis. In regression (1), the coefficient of condition is 0.078 , which is significant at the level of $1 \%$, and in regression (2), the coefficient of condition is 0.121 , which is at the level of $1 \%$ significantly as well. The results all support Hypothesis. That is, when the market environment is not good, the fund uses corporate social responsibility performance for safe investment transfer and turns to stocks with higher corporate social responsibility.

Among fund-level variables, the coefficient of Fund_VOL is significantly negative at the level of 1\%, the coefficient of Fund_BM is significantly positive at the level of $1 \%$, and the coefficient of Fund_ROA is significantly negative at the level of $1 \%$ just in the regression (1), which shows that the fund turns to stocks with higher social responsibility performance, and tends to have lower return volatility, higher book-to-market ratio, or lower return. The coefficient of Difsize is significantly positive, indicating that the fund's investment strategy based on stock market value (transfer from low market value to high market value) is consistent with the direction of corporate social responsibility-based investment strategy; the coefficient of Difbm is significantly negative, indicating that the fund's investment strategy based on the book's book to market value ratio (from a high book to market value ratio to a low book to market value ratio) is consistent with the corporate social responsibility based investment strategy direction.

Table 4. Flight to quality based on corporate social responsibility.

\begin{tabular}{|c|c|c|c|}
\hline Variable & FTQ & (1) & (2) \\
\hline \multirow[t]{3}{*}{ Experiment Variable } & Condition & $0.078(7.04)^{\star * *}$ & $0.121(7.81)^{\star \star *}$ \\
\hline & LnTNA & $0.004(0.94)$ & $0.001(0.35)$ \\
\hline & Turnover & $0.000(0.48)$ & $0.002(1.84)^{*}$ \\
\hline \multirow{4}{*}{$\begin{array}{c}\text { Fund-Level Control } \\
\text { Variables }\end{array}$} & Fund_VOL & $-5.254(8.20)^{\star * *}$ & $-6.273(6.69)^{\star * *}$ \\
\hline & Fund_BM & $0.556(17.51)^{\star * *}$ & $0.824(12.85)^{\star * *}$ \\
\hline & Fund_ROA & $-0.264(1.76)^{\star}$ & $-1.753(9.36)^{\star \star \star}$ \\
\hline & Difbeta & & $-0.001(0.06)$ \\
\hline \multirow{7}{*}{$\begin{array}{c}\text { Alternative Investment } \\
\text { Strategy }\end{array}$} & Difsize & & $0.168(10.82)^{\star * *}$ \\
\hline & Difturnover & & $0.015(0.80)$ \\
\hline & Difbm & & $-0.239(8.95)^{\star * *}$ \\
\hline & Constant & $-0.175(1.84)^{\star}$ & $-0.165(1.93)^{\star}$ \\
\hline & Year & Yes & Yes \\
\hline & Observations & 2740 & 2740 \\
\hline & Adjusted R-Squared & 0.347 & 0.428 \\
\hline
\end{tabular}




\subsection{Robustness Tests}

If the sample year is dominated by a bull or bear market, the test results may be unstable due to an imbalance in the sample distribution. In order to more clearly observe the impact of market performance on fund investment behavior, this article further selects sub-samples before and after the bull-bear market transition for regression. Therefore, this article adopts the following methods when selecting the sub-samples before and after the bull-bear market transition: First, the years before and after the bull-bear market transition are selected. According to the market conditions, it is finally determined as the period of the bull and bear market transition. After determining the sample period, this article selects funds that can obtain data before and after the conversion of the bull and bear market, and finally forms a sub-sample that contains annual data of 1534 funds.

Table 5 shows the regression results of safe investment transfer in the subsamples before and after the bull-bear market transition. As can be seen from Table 5, the coefficients of the explanatory variable are significantly positive, and the results still support Hypothesis. In the bear market, the fund uses corporate social responsibility strategies for safe investment transfer, and turns to stocks with higher corporate social responsibility.

\section{Conclusion}

This paper takes China's stock funds and mixed partial stock funds from 2010 to 2017 as research objects, and studies whether fund managers have flight to quality behaviors due to hedging needs and turns to stocks with higher corporate social responsibility performance when the market is in a poor state.

Table 5. Fund safety investment transfer regression analysis based on sub-samples before and after the bull-bear market transition.

\begin{tabular}{cccc}
\hline Variable & FTQ & $(1)$ & $(2)$ \\
\hline Experiment Variable & Condition & $0.018(2.05)^{* *}$ & $0.052(4.26)^{* * *}$ \\
& LnTNA & $0.005(0.95)$ & $0.003(0.68)$ \\
Fund-Level Control & Turnover & $0.001(0.68)$ & $0.002(1.95)^{*}$ \\
Variables & Fund_VOL & $-5.009(6.89)^{* * *}$ & $-5.356(5.19)^{* * *}$ \\
& Fund_BM & $0.456(12.81)^{* * *}$ & $0.793(10.96)^{* * *}$ \\
& Fund_ROA & $-0.059(0.35)$ & $-1.785(8.46)^{* * *}$ \\
Alternative Investment & Difbeta & & $-0.057(3.08)^{* *}$ \\
Strategy & Difsize & & $0.150(9.32)^{* * *}$ \\
& Difturnover & & $0.016(0.76)$ \\
& Difbm & & $-0.255(8.43)^{* * *}$ \\
& Constant & Yes & Yes \\
& Year & $-0.162(1.41)$ & $-0.201(2.00)^{* *}$ \\
& Observations & 2740 & 2740 \\
& Adjusted R-Squared & 0.347 & 0.428 \\
\hline
\end{tabular}


On the one hand, existing studies have shown that systemic risks are reduced during bull markets, while systemic risks are higher during bear markets. Therefore, there are systematic risk differences in different market environments represented by bull and bear markets. When the market environment is not good, the impact of higher systemic risks on asset portfolios will also increase. At this time, the need for funds to hedge risks is higher. In order to reduce the downside risk of the investment portfolio brought by the poor market environment, the fund will transfer the portfolio assets towards safer stocks for safe investment transfer.

On the other hand, existing research has shown that the companies that actively assume social responsibility can form a reputation insurance effect, which can not only improve the company's ability to resist risks, but also mitigate the negative impact of negative events when negative events occur, and prevent the stock price from falling sharply and losing market value.

Therefore, the research results in this paper show that when the market condition is not good, the systemic risk of the stocks held by the fund is high, and the fund's willingness to hedge risks is enhanced. Fund managers would have flight to quality behavior and turn to invest in stocks with higher corporate social responsibility performance that meets their hedging needs.

The significance of this paper lies in the fact that the existing literature is more about the relationship between investment decisions of fund managers and corporate social responsibility, without considering the path and mechanism of how funds use social responsibility information to make decisions. Therefore, from the perspective of social responsibility performance "Class Insurance" effect, this paper aims to explore whether fund managers have fight to quality behavior and make safe investment transfers to more stocks with good social performance when the market environment is not good?

However, the research in this article still has certain limitations:

First, because fund managers make quarterly shareholding data when making portfolio decisions, the existing corporate social responsibility data are all annual data. To ensure the integrity of the data, this article selects annual data. But the stock market is changing rapidly, and the annual data span is large. Therefore, it is impossible to find more comprehensive standards and methods to evaluate the social responsibility performance of the fund in its investment portfolio.

Second, in this article, the research on fund safe investment transfer behavior selects partial stock funds in stock and hybrid stocks, so it mainly focuses on the safe investment transfer behavior in the stock market. However, the investment objects of the fund are becoming more and more diversified, and whether the fund may also diversify its investments by diverting assets to different financial submarkets (such as investment transfer between the stock market and the bond market). Especially when one of the financial sub-markets is in a turbulent period, is there any risk-avoiding behavior between the markets to divert investment to a more stable financial sub-market? This question deserves further discussion. 


\section{Conflicts of Interest}

The author declares no conflicts of interest regarding the publication of this paper.

\section{References}

Ainsworth, A. B., Fong, K., \& Gallagher, D. R. (2008). Style Drift and Portfolio Management for Active Australian Equity Funds. Australian Journal of Management, 32, 387-418. https://doi.org/10.1177/031289620803200302

Becchetti, L., Ciciretti, R., Hasan, I., \& Kobeissi, N. (2012). Corporate Social Responsibility and Shareholder's Value. Journal of Business Research, 65, 1628-1635.

https://doi.org/10.1016/j.jbusres.2011.10.022

Brown, K. C., Harlow, W. V., \& Starks, L. T. (1996). Of Tournaments and Temptations: An Analysis of Managerial Incentives in the Mutual Fund Industry. The Journal of Finance, 51, 85-110. https://doi.org/10.1111/j.1540-6261.1996.tb05203.x

Cai, Q. F., \& Liu, J. (2012). Performance Ranking, Market State and Risk Adjustment Behavior of Fund Managers: "Fighting for Name" or "Pursuing Profit"? Financial Review, $4,66-76+125$

Capelle-Blancard, G., \& Monjon, S. (2012). Trends in the Literature on Socially Responsible Investment: Looking for the Keys under the Lamppost. Business Ethics: A European Review, 21, 239-250. https://doi.org/10.1111/j.1467-8608.2012.01658.x

Capocci, D., Corhay, A., \& Hübner, G. (2005). Hedge Fund Performance and Persistence in Bull and Bear Markets. The European Journal of Finance, 11, 361-392. https://doi.org/10.1080/1351847042000286676

Chen, F., Hope, O. K., Li, Q., \& Wang, X. (2016). Flight to Quality in International Markets: Investors' Demand for Financial Reporting Quality during Political Uncertainty Events. https://doi.org/10.2139/ssrn.2552173

Chen, Y. J. (2014). The Effect of Corporate Social Responsibility Strategy Selection-A Study Based on the Blood Lead Battery Event. China Population, Resources and Environment, 24, 142-148.

Fu, C., \& Ji, L. (2017). Litigation Risks and Corporate Charitable Donations-An Explanation Based on the Perspective of "Reputation Insurance". Nankai Management Review, 20, 108-121.

Giuli, A. D., \& Kostovetsky, L. (2014). Are Red or Blue Companies More Likely to Go Green? Politics and Corporate Social Responsibility. Journal of Financial Economics 111, 158-180. https://doi.org/10.1016/j.jfineco.2013.10.002

Godfrey, P. C. (2005). The Relationship between Corporate Philanthropy and Shareholder Wealth: A Risk Management Perspective. Academy of Management Review, 30, 777-798. https://doi.org/10.5465/amr.2005.18378878

Godfrey, P. C., Merrill, C. B., \& Hansen, J. M. (2009). The Relationship between Corporate Social Responsibility and Shareholder Value: An Empirical Test of the Risk Management Hypothesis. Strategic Management Journal, 30, 425-445.

https://doi.org/10.1002/smj.750

Hirshleifer, D., Hou, K., \& Teoh, S. H. (2012). The Accrual Anomaly: Risk or Mispricing? Management Science, 58, 320-335. https://doi.org/10.1287/mnsc.1100.1289

Jiang, Y. H., Rao, Y. M., \& Yan, W. J. (2017). Is There Any Buffett in the Bull Market?An Empirical Study Based on the Investment Behavior of Funds in Bull Markets. Investment Research, 36, 52-64. 
Jiang, Y. J., \& Xu, Y. (2012). The Impact of Corporate Social Responsibility on Shareholder Wealth in the Occurrence of Negative Events. Zhongda Management Research, 7, 102-120.

Kao, G. W., Cheng, L. T. W., \& Chan, K. C. (1998). International Mutual Fund Selectivity and Market Timing during up and down Market Conditions. Financial Review, 33, 127-144. https://doi.org/10.1111/j.1540-6288.1998.tb01373.x

Kempf, A., Ruenzi, S., \& Thiele, T. (2009). Employment Risk, Compensation Incentives, and Managerial Risk Taking: Evidence from the Mutual Fund Industry. Journal of Financial Economics, 92, 92-108. https://doi.org/10.1016/j.jfineco.2008.05.001

Li, W. J., \& Lu, X. Y. (2015). Do Institutional Investors Pay Attention to the Environmental Performance of Enterprises?-Empirical Evidence from Listed Companies in China's Heavy Pollution Industries. Financial Research, No. 12, 97-112.

Lins, K. V., Servaes, H., \& Tamayo, A. (2017). Social Capital, Trust, and Firm Performance: The Value of Corporate Social Responsibility during the Financial Crisis. The Journal of Finance, 72, 1785-1824. https://doi.org/10.1111/jofi.12505

Mao, L., Wang, Z. J., \& Wang, L. L. (2012). Institutional Investor's Shareholding Preference, Selection Strategy and Corporate Social Performance. Management Science, 25, 21-33.

Margolis, J. D., \& Walsh, J. P. (2003). Misery Loves Companies: Rethinking Social Initiatives by Business. Administrative Science Quarterly, 48, 268-305. https://doi.org/10.2307/3556659

$\mathrm{Ng}$, J. (2011). The Effect of Information Quality on Liquidity Risk. Journal of Accounting and Economics, 52, 126-143. https://doi.org/10.1016/j.jacceco.2011.03.004

Shiu, Y. M., \& Yang, S. L. (2015). Does Engagement in Corporate Social Responsibility Provide Strategic Insurance-Like Effects? Strategic Management Journal, 38, 455-470. https://doi.org/10.1002/smj.2494

Song, X. Z., Hu, Y., \& Li, S. H. (2017). Social Responsibility Information Disclosure and the Risk of Stock Price Collapse-A Path Analysis Based on Information Effect and Reputation Insurance Effect. Financial Research, No. 4, 161-175.

Sun, Z. L., Ren, Y., Lin, J. Y., \& Li, Y. H. (2018). Research on the Relationship between Corporate Social Responsibility and Fund Shareholding Ratio. Knowledge Economy, No. 12, 113-114.

Vayanos, D. (2004). Flight to Quality, Flight to Liquidity, and the Pricing of Risk. National Bureau of Economic Research. https://doi.org/10.3386/w10327

Wright, F., \& Hiller, K. (1995). Competitiveness Through Management of Diversity: Effects on Stock Price Valuation. Academy of Management Journal, 38, 272-287. https://doi.org/10.2307/256736

Xiao, J. (2013) The Stock Market Cycle and the Choice of Fund Investors. Economics (Quarterly), 12, 1299-1320.

Xiao, J. H. (2016). Effects of Fund Performance on Investors' Purchase and Redemption Behavior: Evidence Considering Stock Market Performance. Audit \& Economic Research, 31, 89-100.

Zhang, Z. G., Jin, X. C., \& Li, G. Q. (2013). Empirical Research on the Intertemporal Impact of Corporate Social Responsibility and Financial Performance. Accounting Research, No. 8, 32-39+96. 